\title{
Holocene malacofauna in calcareous deposits of Dūkšta site near Maišiagala in Lithuania
}

\author{
Aleksander Sanko, \\ Algirdas Gaigalas, \\ Eugenija Rudnickaitè, \\ Monika Melešytè
}

Sanko A., Gaigalas A., Rudnickaitė E., Melešyte M. Holocene malacofauna in calcareous deposits of Dūkšta site near Maišiagala in Lithuania. Geologija. Vilnius. 2008. Vol. 50. No. 4(64). P. 290-298. ISSN 1392-110X

The paper contains results of new investigations in Lithuania of the first occurrences of terrestrial molluscs in calcareous tufa (travertine), carbonate content and radiocarbon dating. Terrestrial fossil molluscs (35 taxa) prevail in the mollusc fauna, while freshwater species are much more rare (6 taxa). The Dükšta terrestrial mollusc fauna embraces a complex of thermophiles including such forest species as Acicula polita (Hartmann), Acanthinula aculeata (Müller), Aegopinella cf. pura (Alder), Bulgaria cana (Held) and Discus cf. rotundatus (Müller), as well as mainly South European Carychium tridentatum (Risso) and mainly West European Vertigo moulinsiana (Dupuy). The radiocarbon age of the sediments was found to correspond to the end of the Atlantic climatic period and the beginning of the Subboreal.

Key words: malacofauna, calcareous deposits, radiocarbon age, Holocene, Lithuania

Received 17 March 2008, accepted 15 September 2008

Aleksander Sanko. Department of Physical Geography, Belarus State Pedagogical University, Sovetskaya str. 18, 220030 Minsk, Belarus. E-mail: sankoaf@tut.by; Algirdas Gaigalas, Eugenija Rudnickaitė, Monika Melešytė. Department of Geology and Mineralogy, Vilnius University, M. K. Čiurlionio 21/27, LT-03101 Vilnius, Lithuania. E-mail: Algirdas.Gaigalas@gf.vu.lt; Eugenija.Rudnickaite@gf.vu.lt

\section{INTRODUCTION}

The Dūkšta occurrence of buried malacofauna as one of the first occurrences of fossil terrestrial molluscs in Lithuania has been found and explored in Central Lithuania near Maišiagala in the outskirts of Bradeliškes village (Fig. 1). This place is related to occurrence of calcareous spring tufa (travertine) exposed on a slope of the right bank of the Dūkšta rivulet valley. The site of the calcareous tufa deposit surface lies 6-7 $\mathrm{m}$ above the river water boundary and borders on a 8-10-m high river terrace, its base being formed by yellowish-brown till loam (Fig. 2). The terrace setup shows a trail of calcareous tufa with rare mollusc shells most likely formed due to slope processes.

\section{DESCRIPTION OF THE SECTION AND CALCAREOUS DEPOSITS}

The Dūkšta calcareous spring tufa in the main deposits is represented by grainy, lumpy and farinaceous texture with inclusions, in some layers, of organic matter, sometimes wood and mollusc shells. The thickness of calcareous tufa exceeds $3.5 \mathrm{~m}$. It occurs above the sand-gravel/till deposits and is covered only by recent soil.

Mollusc shells are concentrated in grainy and lumpy calcareous tufa enriched with organics. Farinaceous tufa contains few or no shells.
Description of section. From top to bottom lie the following strata:

$\mathbf{0 . 0 0 - 0 . 3 0 ~ m ~ - ~ r e c e n t ~ s o i l , ~ p o d s o l ; ~}$

0.30-0.76 m - sand, fine-grained, silty, dark grey, quartz dominates, feldspars rare, calcareous, total carbonate content $33.54-38.46 \%$;

0.76-1.00 $\mathrm{m}$ - calcareous tufa in silt and clay fractions, dark grey, total carbonate content $90.54-90.73 \%$, tufa samples No. 4 for carbon isotopes;

1.00-1.31 m - calcareous loam, silty, with different content of carbonates (68.00-91.30\%), dark grey;

1.31-2.00 $\mathrm{m}$ - calcareous tufa in sand and silt fractions (travertine), bright yellowish grey, carbonate content 88.70-99.93\%, tufa samples No. 3 for carbon isotopes;

2.00-2.21 m - peat, brown, with wood remains, total carbonate content $58.27-88.70 \%$, wood samples No. 3 for radiocarbon;

2.21-2.45 $\mathrm{m}$ - calcareous tufa in sand and silt fractions (travertine), bright grey, total carbonate content $62.76-70.63 \%$;

2.45-2.90 $\mathrm{m}$ - peaty soil, dark, with wood remains, interlayers of sand and silt in the lower part, total carbonate content 13.21-58.08\%, wood sample No. 1 for radiocarbon;

2.90-3.11 $\mathrm{m}$ - calcareous tufa in sand and silt fractions (travertine), dark brown, ferruginised, total carbonate content 69.32-80.56-99.49\%, tufa samples No. 2 for carbon isotopes; 


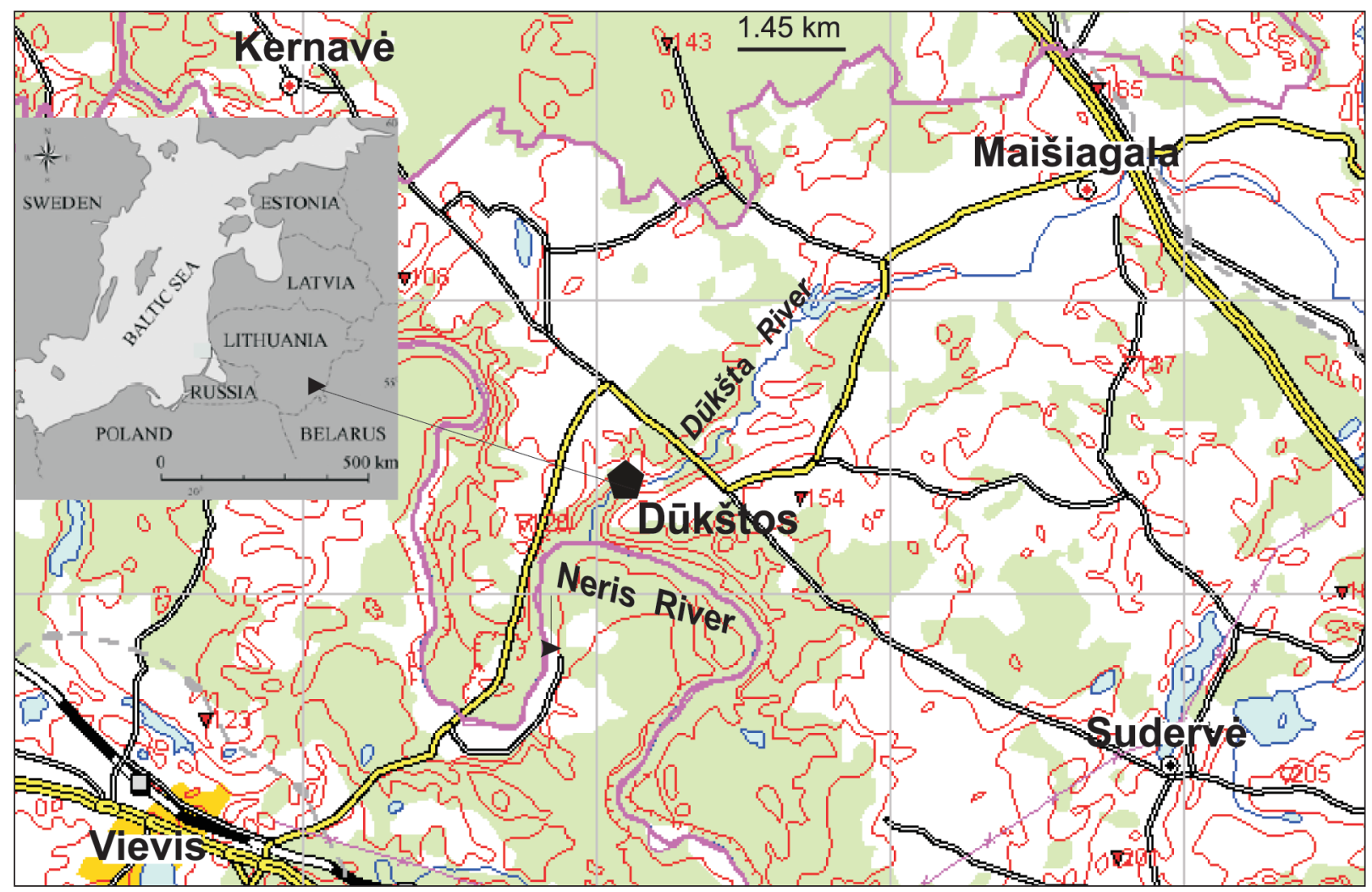

Fig. 1. Location of the Dükšta section

1 pav. Dükštos pjūvio padètis

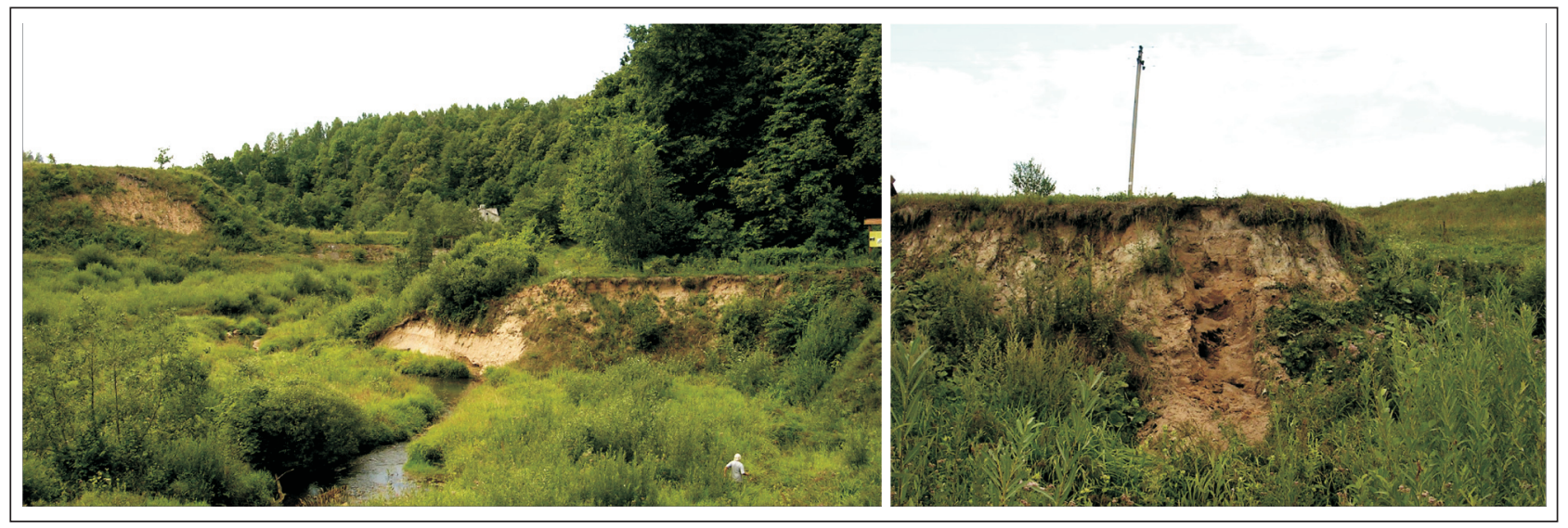

Fig. 2. The Dükšta River valley (on the left side) and an exposure of calcareous tufa with mollusc fauna in the slope of a plane 8-10 m above water level in the Dūkšta River (on the right side)

2 pav. Vaizdas ị Dūkštos upẻs slèni (kaireje pusẻje) ir karbonatinio tufo su moliuskais atodanga Dūkštos upès slėnio aikštelès, pakylančios 8-10 m virš vandens lygio, šlaite (dešinèje pusejje)

3.11-3.29 m - sand, peaty, dark brown, ferruginised, laminated, with organogenic and wood remains, wood samples No. 1 and No. 4 for radiocarbon;

3.29-3.54 m - travertine, total carbonate content 99.57\%, travertine samples No. 1 for carbon isotopes;

3.54-3.74 m - sand, brown yellowish, fine-grained, total carbonate content $28.95-31.20 \%$;

3.74-3.90 m - travertine, hard, breaks into pieces, total carbonate content $98.73 \%$;
3.90-4.22 m - sand, coarse-grained, with gravel, pebbles and boulders, total carbonate content $20.14 \%$;

$4.22 \mathrm{~m}$ and deeper - till, brown, boulder loam, calcareous.

Calcareous deposits. In addition to other methods, carbonate analysis was used as well. The content of carbonates in the sediments was studied for the reconstruction of palaeosedimentary environments. The Dūkšta outcrop sediments were investigated in 34 samples by the method of Scherbina (Щербина, 1958) 
improved by us (Rudnickaitè, 1980). Not only calcite, but also dolomite could be determined by this method. Total carbonate content determined by this method is usually higher than that determined by other techniques such as those of Kozlovskij or titration, etc. The carbonate content of tufa sediments was determined for a bulk sample. The calcimeter was used to determine $\mathrm{CO}_{2}$ volume in the cross-section of the Dükšta outcrop. It enabled us not only to obtain data on calcite, but also on dolomite content in the sediments. It allows also to determine other carbonate minerals, if they are present in significant amounts. It is known that the released $\mathrm{CO}_{2}$ volume after 30 seconds of reacting with $5 \mathrm{ml}$ of $5 \%$ cold $\mathrm{HCl}$ with powdered sediment or rocks indicates calcite. Later, the released volume of $\mathrm{CO}_{2}$ plus the volume released after heating to $40{ }^{\circ} \mathrm{C}$ for 3 minutes indicates dolomite content. By the volume of $\mathrm{CO}_{2}$ related to calcite and dolomite, we calculated the percentage of the mentioned minerals. The percentage of $\mathrm{Ca}$ and $\mathrm{Mg}$ oxides could be recalculated if needed.

Samples for carbonate analysis were taken from separate lithological beds. For the description of the cross-section of the outcrop in the field, the sampling interval was $5-10 \mathrm{~cm} .50 \mathrm{~g}$ of the sample was taken for analysis. Samples were powdered, and $0.2 \mathrm{~g}$ was weighed for carbonate analysis. Prior to carbonate analysis, 2 or 3 samples of pure calcite $(0.2 \mathrm{~g})$ were analysed. The same procedure was repeated after each five samples. These measurements were used to calculate the calibration coefficient $(k)$ which is temperature- and atmospheric pressure-dependent:

$$
k=44 / x \text {, where } x \text { is the pure calcite } \mathrm{CO}_{2} \text { value. }
$$

The carbonate analysis data of the Dūkšta outcrop are presented in Table 1 and Fig. 3.
A distinctive feature is that the dolomite percentage is lower than that of calcite in all the cross-section (Fig. 3 and Table 1).

When applying carbonate content data, it is important to consider the overall regime and the sedimentary environment. Carbonate content may be to some extent elevated by the allochthonous detrital part of sediments. The interpretation of carbonate content data should be integrative. Otherwise it could be misleading.

The vertical variation of carbonates reflects sedimentary environments and the past climate. The mentioned data enable to reveal the general features of the sedimentation conditions. Three layers of peat and peaty soil with wood remains were distinguished in the study section: the upper $2.00-2.21 \mathrm{~m}$, middle $2.45-2.90 \mathrm{~m}$ and lower $3.30-3.54 \mathrm{~m}$ deep. The predominance of natural factors in sedimentation processes were manifested in the mean values of $\mathrm{CaCO}_{3}$ and $\mathrm{CaMg}\left(\mathrm{CO}_{3}\right)_{2}$ : in the upper layer $58.27-88.70 \%$, the middle layer $13.21-56.0 \%$ and in the lower layer of peaty sediments $28.10-31.20 \%$. Carbonate compounds can be either of allochthonous or autochthonous origin. The proportion of carbonate matter derived from these sources is a function of groundwater characteristics in relation to organic productivity. Carbonaceous sediments (calcareous tufa and travertine) are accumulated by groundwater and mineralized by mollusk shells. The values for carbonaceous matter in tufa sediments and travertine are higher than in the layers of peaty sediments and vary from $62.76 \%$ to $99.85 \%$. Peaty sediments of the three layers reflect the time intervals of the drying of climate. The groundwater levels were low. The increasing humidity and a rize of groundwater level were favourable for calcareous sediments (tufa and travertine layers) in the study area.
Fig. 3. Carbonate content in sediments the Dükšta section. 1 - sand, 2 - sand with gravel and boulders, 3 - calcareous tufa (travertine), 4 - interlayers of humic organics with wood remnants, 5 - calcareous loam and sandy loam, 6 - recent soil, $7-\mathrm{CaCO}_{3}$ (calcite), 8 - sampling points, $9-\mathrm{CaMg}\left(\mathrm{CO}_{3}\right)_{2}$ (dolomite), 10 - total carbonate content

3 pav. Dūkštos pjūvio nuosėdų karbonatingumas. 1 - smèlis, 2 - smèlis su žvirgždu ir rieduliais, 3-karbonatinis tufas (travertinas), 4-humusingos organikos tarpsluoksniai su medienos liekanomis, 5-karbonatingas priesmèlis ir priemolis, 6- dabartinis dirvožemis, $7-\mathrm{CaCO}_{3}$ (kalcitas), 8 - pavyzdžių paèmimo vietos, 9 - $\mathrm{CaMg}\left(\mathrm{CO}_{3}\right)_{2}$ (dolomitas), 10 - bendras karbonatingumas

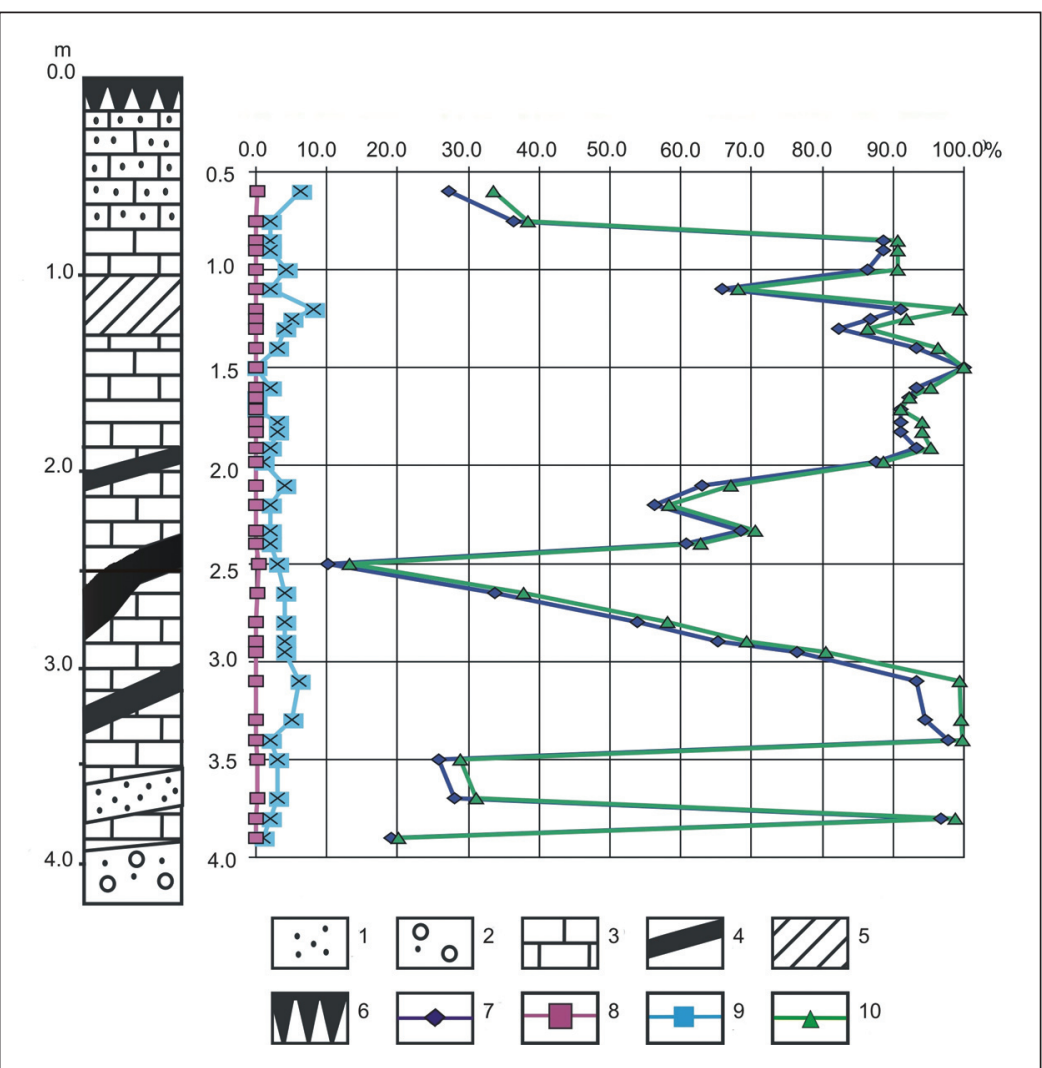


Table 1. Carbonate content of sediments in the Dükšta outcrop, \% 1 lentelè. Tyrinètos Dükštos atodangos nuogulų karbonatingumas (\%)

\begin{tabular}{|c|c|c|c|c|c|}
\hline $\begin{array}{c}\text { Sample } \\
\text { No. }\end{array}$ & $\begin{array}{c}\text { Depth, } \\
\text { cm }\end{array}$ & Calcite & Dolomite & $\begin{array}{c}\text { Total } \\
\text { amount }\end{array}$ & dol:calc \\
\hline 1 & 0.60 & 27.28 & 6.26 & 33.54 & 0.23 \\
\hline 2 & 0.75 & 36.37 & 2.08 & 38.45 & 0.06 \\
\hline 3 & 0.85 & 88.65 & 2.08 & 90.73 & 0.02 \\
\hline 4 & 0.90 & 88.65 & 2.08 & 90.73 & 0.02 \\
\hline 5 & 1.00 & 86.37 & 4.17 & 90.54 & 0.05 \\
\hline 6 & 1.10 & 65.92 & 2.08 & 68.00 & 0.03 \\
\hline 7 & 1.20 & 91.14 & 8.16 & 99.30 & 0.09 \\
\hline 8 & 1.25 & 86.69 & 5.11 & 91.80 & 0.06 \\
\hline 9 & 1.30 & 82.25 & 4.08 & 86.33 & 0.05 \\
\hline 10 & 1.40 & 93.36 & 3.06 & 96.42 & 0.03 \\
\hline 11 & 1.50 & 99.93 & 0.00 & 99.93 & 0.00 \\
\hline 12 & 1.60 & 93.37 & 2.04 & 95.41 & 0.02 \\
\hline 13 & 1.65 & 92.25 & 0.00 & 92.25 & 0.00 \\
\hline 14 & 1.71 & 91.14 & 0.00 & 91.14 & 0.00 \\
\hline 15 & 1.78 & 91.04 & 3.10 & 94.14 & 0.03 \\
\hline 16 & 1.83 & 91.04 & 3.10 & 94.14 & 0.03 \\
\hline 17 & 1.91 & 93.29 & 2.06 & 95.35 & 0.02 \\
\hline 18 & 1.98 & 87.67 & 1.03 & 88.70 & 0.01 \\
\hline 19 & 2.10 & 62.94 & 4.13 & 67.07 & 0.07 \\
\hline 20 & 2.20 & 56.20 & 2.07 & 58.27 & 0.04 \\
\hline 21 & 2.33 & 68.56 & 2.07 & 70.63 & 0.03 \\
\hline 22 & 2.40 & 60.69 & 2.07 & 62.76 & 0.03 \\
\hline 23 & 2.50 & 10.11 & 3.10 & 13.21 & 0.30 \\
\hline 24 & 2.65 & 33.72 & 4.13 & 37.85 & 0.12 \\
\hline 25 & 2.80 & 53.95 & 4.13 & 58.08 & 0.07 \\
\hline 26 & 2.90 & 65.20 & 4.12 & 69.32 & 0.06 \\
\hline 27 & 2.95 & 76.43 & 4.13 & 80.56 & 0.05 \\
\hline 28 & 3.10 & 93.29 & 6.20 & 99.49 & 0.06 \\
\hline 29 & 3.30 & 94.41 & 5.16 & 99.57 & 0.05 \\
\hline 30 & 3.40 & 97.78 & 2.07 & 99.85 & 0.02 \\
\hline 31 & 3.50 & 25.85 & 3.10 & 28.95 & 0.12 \\
\hline 32 & 3.70 & 28.10 & 3.10 & 31.20 & 0.11 \\
\hline 33 & 3.80 & 96.66 & 2.07 & 98.73 & 0.02 \\
\hline 34 & 3.90 & 19.11 & 1.03 & 20.14 & 0.050 \\
\hline
\end{tabular}

For radiocarbon dating and stable isotopic analysis of calcareous sediments, four samples of carbonates were collected. The results of radiocarbon dating are presented in Table 2. According to the radiocarbon dating, sedimentation of calcareous tufa (travertine) in the Dükšta site lasted more than 3000 years. The calibrated age ranges from 2250 to $6470 \mathrm{BC}$. The sedimentation rate of all deposits in the Dūkšta section was about $0.9 \mathrm{~mm} /$ year.

Interpretation of the analytical data obtained with the stable isotope ${ }^{13} \mathrm{C}$ helps to solve the problem of formation temperature, environmental conditions and the genesis of calcareous sediments in the Dükšta section. The obtained $\delta^{13} \mathrm{C}$ are nearly indentical to the four samples of calcareous tufa (Table 2). The identity of $\delta^{13} \mathrm{C}$ content in all sections of calcareous tufa indicates the stability of spring water temperature during tufa sedimentation. Carbon $\left({ }^{13} \mathrm{C}\right)$ stable isotope shows the cool groundwater conditions during the sedimentation of calcareous sediments from an underground spring in the study area.

\section{MOLLUSC FAUNA}

The taxonomic composition of fossil molluscs detected in the Dūkšta calcareous sediments is presented in Table 3. Terrestrial fossil molluscs (35 taxa) prevail, while fresh-water species are significantly more rare (6 taxa).

From the ecological viewpoint, the terrestrial fauna consists of forest species (11 taxa), open areas species ( 3 taxa) and mesophiles typical of changing living conditions (21 taxa). Except the mesophiles, the two other ecological groups indicate that forests prevailed in the area and covered $78.6 \%$. The forest species detected most often were Perforatella bidentata (Gmelin) and Acicula polita (Hartmann). The East European species Perforatella bidentata (Gmelin) prefers wet alder thickets. The Central European species Acicula polita (Hartmann) now occupies moderately wet deciduous forests. There were also broadleaved species indicated by presence of inhabitants of mainly broad-leaved forests, such as Acanthinula aculeata (Müller), Aegopinella cf.pura (Alder), Discus cf. rotundatus (Müller).

The most widely spread species of open biotopes is Vallonia costata (Müller) inhabiting mainly meadows with low grass or rarely sand dunes, light forests or bog edges. Its constant codweller V.pulchella (Müller) is significantly lower in number.

Table 2. Results of radiocarbon dating of calcareous sediments from the Dūkšta section (results by N. D. Mikhailov, 2008) 2 lentelè. Dūkštos pjūvio karbonatinių nuogulų radiokarboninès datos

\begin{tabular}{|c|c|c|c|c|c|c|c|}
\hline \multirow[t]{2}{*}{ No. } & \multirow{2}{*}{$\begin{array}{c}\text { Sample No } \\
\text { and depth (m) }\end{array}$} & \multirow{2}{*}{$\begin{array}{l}\text { Sample } \\
\text { material }\end{array}$} & \multirow{2}{*}{$\begin{array}{l}\text { Laboratory } \\
\text { number }\end{array}$} & \multirow{2}{*}{$\begin{array}{l}{ }^{14} \mathrm{C} \text { age } \\
\text { (yr BP) }\end{array}$} & \multirow{2}{*}{$\delta^{13} \mathrm{C}, \%$ PDB } & \multicolumn{2}{|c|}{$\begin{array}{c}\text { Calibrated age range(s) } \mathrm{BC} \text { or } \\
\mathrm{AD}\end{array}$} \\
\hline & & & & & & $1 \delta(68.3 \%)$ & $2 \delta(95.4 \%)$ \\
\hline 1 & $\begin{array}{l}\text { No. } 1 \\
3.5\end{array}$ & Calcareous tufa & IGSB-1366 & $7450 \pm 100$ & -9.3 & $6420-6230$ BC & $6470-6080 \mathrm{BC}$ \\
\hline 2 & $\begin{array}{c}\text { No. } 2 \\
3.0\end{array}$ & Calcareous tufa & IGSB-1367 & $7440 \pm 90$ & -10.0 & $6410-6230$ BC & $6460-6090$ BC \\
\hline 3 & $\begin{array}{c}\text { No. } 3 \\
1.35\end{array}$ & Calcareous tufa & IGSB-1368 & $6660 \pm 185$ & -10.0 & $5650-5510 \mathrm{BC}$ & $5720-5470$ BC \\
\hline 4 & $\begin{array}{l}\text { No. } 4 \\
0.8\end{array}$ & Calcareous tufa & IGSB-1369 & $3990 \pm 70$ & -10.1 & $\begin{array}{l}2620-2430 \mathrm{BC} \\
2420-2400 \mathrm{BC} \\
2380-2340 \mathrm{BC}\end{array}$ & $\begin{array}{l}2900-2800 \mathrm{BC} \\
2750-2250 \mathrm{BC}\end{array}$ \\
\hline
\end{tabular}


Table 3. Fauna of mollusc calcareous tufa in the Dükšta section, 2006

3 lentelè. Moliuskų fauna (vnt.) iš Dūkštos atodangos karbonatinių tufų (2006)

\begin{tabular}{|c|c|c|c|c|c|c|c|c|c|c|}
\hline \multirow{2}{*}{ Taxon } & \multicolumn{10}{|c|}{ Samples } \\
\hline & 1 & 2 & 3 & 4 & 5 & 6 & 7 & 8 & 9 & 10 \\
\hline Acicula polita (Hartmann) & 2 & 92 & & 183 & 182 & 9 & 4 & & 17 & 1 \\
\hline Acanthinula aculeata (Müller) & & & & 6 & 10 & 1 & & & 1 & \\
\hline Discus ruderatus (Férussac) & & 12 & 2 & 45 & 55 & 7 & 1 & & & \\
\hline Aegopinella cf. pura (Alder) & & & & & & 3 & & & & \\
\hline Clausilia cruciata (Studer) & & 2 & & & & & & & 1 & \\
\hline Clausiliidae gen. & 1 & 40 & & 10 & 9 & 7 & & & & 2 \\
\hline Bulgaria cana (Held) & & & & & 1 & & 1 & 17 & 25 & \\
\hline Discus cf. rotundatus (Müller) & & & & 3 & & & & & 1 & \\
\hline Vitrea crystallina (Müller) & & & & & & 3 & & 11 & 46 & 6 \\
\hline Bradybaena fruticum (Müller) & & 2 & & 5 & 5 & & 1 & & 1 & \\
\hline Perforatella bidentata (Gmelin) & 1 & 139 & 4 & 150 & 242 & 71 & 80 & 30 & 53 & 7 \\
\hline Pupilla muscorum (Linnaeus) & & & 2 & & & & & & 2 & 15 \\
\hline Vallonia costata (Müller) & 4 & 97 & 27 & 680 & 737 & 18 & & 10 & 97 & 52 \\
\hline Vallonia pulchella (Müller) & & 11 & 1 & 40 & 45 & 2 & 1 & 13 & 40 & 33 \\
\hline Cochlicopa lubrica (Müller) & & 5 & 10 & 10 & 23 & 1 & 2 & 17 & 10 & 6 \\
\hline Vertigo alpestris Alder & & & & 1 & 1 & & & & 2 & 1 \\
\hline Punctum pygmaeum (Draparnaud) & & 1 & 14 & 10 & 21 & 1 & & & 8 & \\
\hline Nesovitrea hammonis (Strom) & 2 & 22 & 8 & 200 & 130 & 1 & & 80 & 10 & \\
\hline Limacidae gen. & & 5 & 2 & 20 & 24 & 4 & 2 & 2 & 5 & 1 \\
\hline Euconulus fulvus (Müller) & & & 6 & 6 & 11 & & & 4 & 13 & \\
\hline Trichia hispida (Linnaeus) & & & & & & & & & & 2 \\
\hline Carychium tridentatum (Risso) & & 19 & 4 & 53 & 85 & 3 & 4 & 10 & 30 & 1 \\
\hline Columella edentula (Draparmaud) & & & 1 & 4 & & & & 5 & 2 & \\
\hline Vertigo angustior (Jeffreus) & 3 & 63 & 39 & 575 & 691 & 10 & & & 19 & 2 \\
\hline Vertigo substriata (Jeffreus) & & 1 & 21 & 33 & 22 & 1 & 1 & 7 & 5 & 1 \\
\hline Succinea oblonga (Draparnaud) & & & & & & & & & & 12 \\
\hline Nesovitrea petronella (L. Pfeiffer) & & 4 & 2 & 10 & 24 & & 2 & & & \\
\hline Carychium minimum Müller & 1 & 160 & 69 & 700 & 831 & 15 & 10 & 137 & 202 & 1 \\
\hline Cochlicopa nitens (Gallenstein) & & & & 1 & 1 & & & & & \\
\hline Vertigo antivertigo (Draparnaud) & & & & & & & & & 4 & \\
\hline Vertigo moulinsiana (Dupuy) & & & & & & & & & & 3 \\
\hline Succinea putris (Linnaeus) & & 7 & 6 & 7 & 8 & 3 & 5 & 15 & 48 & 19 \\
\hline Succinea elegans (Risso) & & & & 1 & & & & 1 & 15 & \\
\hline Zonitoides nitidus (Müller) & 3 & 1 & 4 & 21 & 61 & 2 & 7 & 21 & 10 & \\
\hline Monachoides rubiginosa (Schmidt) & & & & & & & & 3 & & \\
\hline Valvata cristata Müller & & & & & 1 & & & & & \\
\hline Valvata pulchella (Studer) & & 1 & & & & & & & & \\
\hline Lymnaea truncatula (Müller) & 1 & 3 & 14 & 90 & 58 & 13 & 45 & 72 & 79 & 9 \\
\hline Lymnaea stagnalis (Linnaeus) & & & & & & & & & & 2 \\
\hline Pisidium casertanum (Poli) & & 12 & & 300 & 132 & 4 & 21 & & 20 & \\
\hline Pisidium personatum Malm & & 4 & & 50 & 38 & & 30 & 1 & 13 & \\
\hline Total & 18 & 703 & 236 & 3214 & 3448 & 179 & 217 & 456 & 779 & 176 \\
\hline
\end{tabular}

Among mesophiles, the conditions were most favourable for Carychium minimum Müller and Vertigo angustior (Jeffreus). Carychium minimum Müller prefers low, moist and wet sites at the margins of bogging lakes. Vertigo angustior (Jeffreus) now occupies wet meadows in moss and grass, as well as lake shores. Shells of this species occur most often in Boreal deposits. The Dūkšta terrestrial mollusc fauna embraces a complex of thermophiles including such forest species as Acicula polita (Hartmann), Acanthinula aculeata (Müller),
Aegopinella cf. pura (Alder), Bulgaria cana (Held) and Discus cf. rotundatus (Müller), as well as mainly South-European Carychium tridentatum (Risso) and mainly West-European Vertigo moulinsiana (Dupuy) (Fig. 4). Let us focus on the last species, V. moulinsiana (Dupuy), belonging to a group of thermophilic relicts. Its position within the ecological groups in the Netherlands is as follows: forest molluscs make up 28.6\%, open biotope species 0 , mesophiles $7.1 \%$, and hydrophiles $50 \%$ (Meijer, 1985). This species prefers certain climatic conditions: 
high air moisture, annual precipitation at least $600 \mathrm{~mm}$, the mean annual temperature of $10^{\circ} \mathrm{C}$; the mean July temperature of $15^{\circ} \mathrm{C}$, and the mean January temperature above $-5^{\circ} \mathrm{C}$; the recent spreading of the species takes place mainly south of the $17^{\circ} \mathrm{C}$ isoline (Johansen, 1904). The species withstands temperatures within the range of -10 to $+30{ }^{\circ} \mathrm{C}$ (Butot, Neuteboom, 1958). These data indicate more favourable climatic conditions than those in the Vilnius area now.

The distribution of mollusc shells in the profile is in a malacological diagram (Fig. 5) showing how deposits were accumulating in six local malacological zones. The start of deposit formation coincides with a high representation of the Central Europian forest mollusc Acicula polita (Hartmann) (zone A. p.). The homonymous local zone reflects optimal climatic conditions which most likely should be attributed to the climatic optimum in the Holocene, i. e. its Atlantic period.

The next local zone is characterised by the following mesophilic species: Carychium minimum Müller, Carychium tridentatum (Risso), Vertigo angustior (Jeffreus) (zone C. t. + C. m.). An open bogged landscape started to prevail at that time in the vicinity of the profile with numerous Vallonia costata (Müller) specimens. However, soon forests occupied the area around the source. Wet alder thickets became more abundant, providing conditions favourable for the species Perforatella bidentata (Gmelin) under the canopy (zone P. b.). Later, the progressing humidity disturbed the functioning of the source, expressed in the replacement of calcareous tufa with humic sandy loam and loam, as well as in formation of a small lake in which the role of water molluscs, especially Lymnaea truncatula (Müller) (zone L.t.), increased. This typical amphibiotic species inhabits shallow overgrowing lakes, bogs and pools with a silty or clayey bottom. Soon the source regenerated, and mesophilic and hydrophilic fauna with prevailing Carychium minimum Müller, Nesovitrea hammonis (Ström) and Cochlicopa lubrica (Müller) populated its environs (zone C. m. + N.h.). At the final stage of the sources in the Dükšta valley, the role of open landscape species, such as Vallonia costata (Müller) and V. pulchella (Müller), increased (zone V.c.). This seems to be related to forest felling by man. The disappearance of forests in the vicinity of the profile disturbed the hydrological regime in the underground and stopped the activity of sources and the formation of recent soil. The malacocenosis taken from the recent soil indicates that even more open landscape species played the leading role in the malacological spectrum, showing that the deforestation was increasing.

The distribution of the ecological groups of molluscs is illustrated on bi-component diagram (Fig. 6). The optimal environment for mollusc fauna occurred during the sedimentation of the lowermost part of the section (depth interval 2.5 to $3.5 \mathrm{~m}$ ) where most specimens of molluscs $\left(\mathrm{N}_{\mathrm{s}}\right)$ and the highest carbonate material content were established.

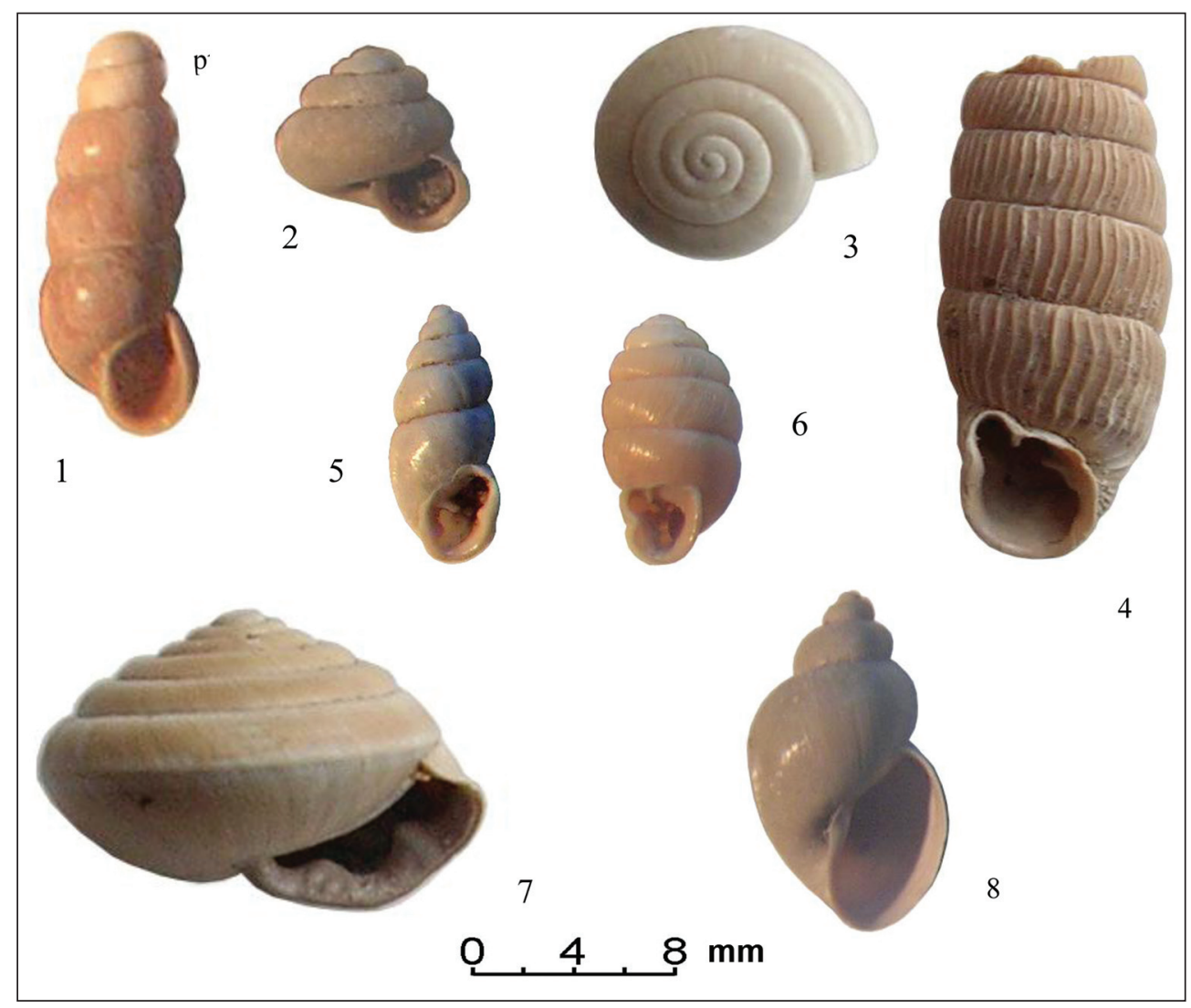

Fig. 4. Shells of the characteristic molluscs from the Dükšta section deposits:

1 - Acicula polita (Hartmann), 2 - Acanthinula aculeata (Müller), 3 - Vitrea crystallina (Müller), 4 - Bulgaria cana (Held), 5 - Perforatella bidentata (Gmelin), 8 - Lymnaea truncatula (Müller) 4 pav. Dükštos pjūvio nuogulose surastų büdingiausių moliuskų kriauklès:

1 - Acicula polita (Hartmann), 2 - Acanthinula aculeata (Müller), 3 - Vitrea crystallina (Müller), 4 - Bulgaria cana (Held), 5 - Perforatella bidentata (Gmelin), 8 - Lymnaea truncatula (Müller) 


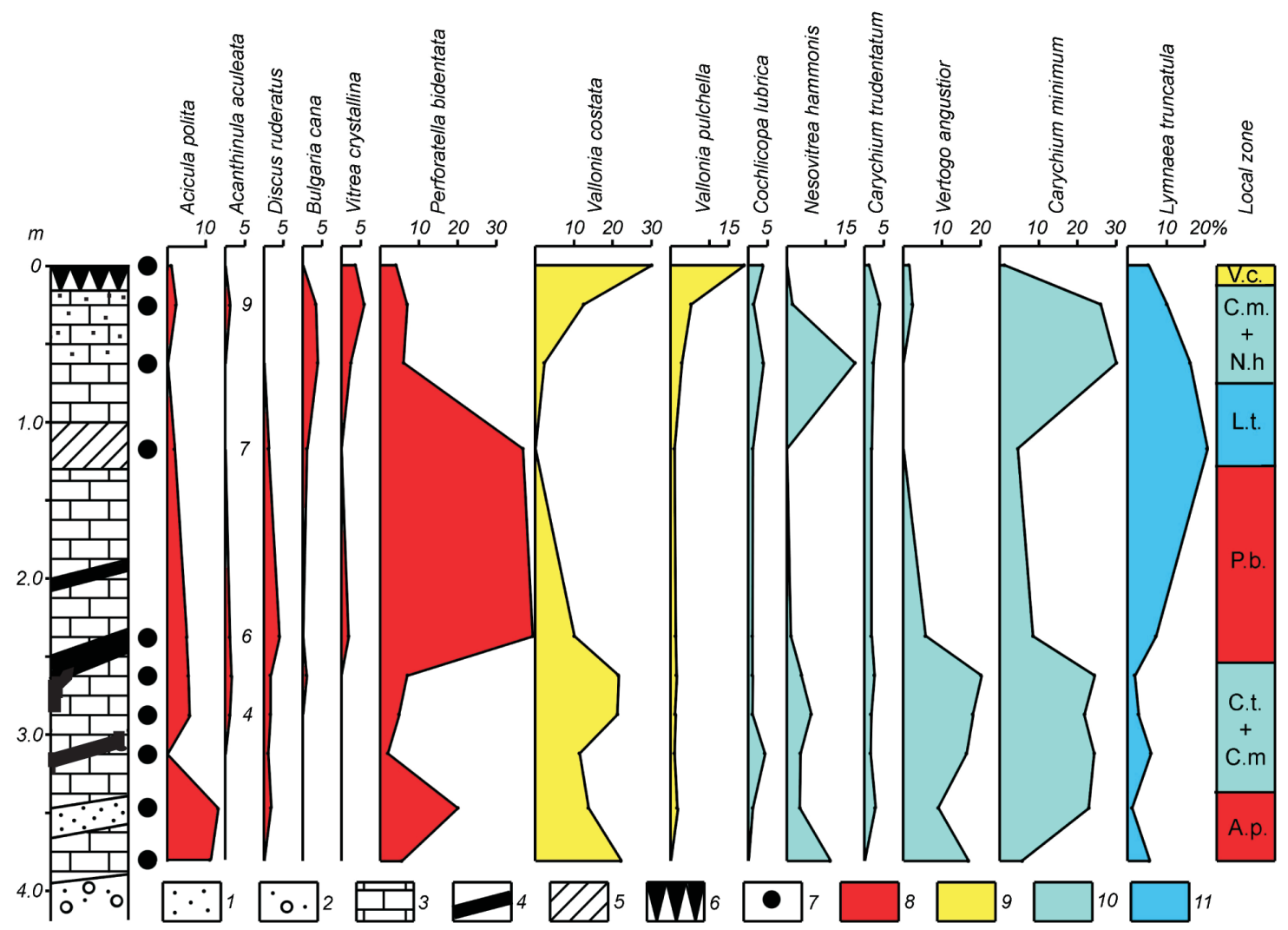

Fig. 5. Malacological diagram of calcareous deposits in the Dūkšta section.

1 - sand, 2 - sand with gravel and pebble, 3 - calcareous tufa (travertine), 4 - interlayers of humic organics with wood remains, 5 - calcareous loam and sandy loam with carbonates, 6 - recent soil, 7 - sampling points, 8 - forest molluscs, 9 - molluscs of open areas, 10 - mesophilic molluscs, 11 - freshwater molluscs

5 pav. Dūkštos pjūvio nuogulų malakofaunos diagrama.

1 - smèlis, 2 - smèlis su žvirgždu ir rieduliais, 3 - karbonatinis tufas (travertinas), 4 - humusingos organikos tarpsluoksniai su medienos liekanomis, 5 - karbonatingas priesmèlis ir priemolis,

6 - dabartinis dirvožemis, 7 - pavyzdžių paėmimo vietos, 8 - miško moliuskai, 9 - atvirų plotų moliuskai, 10 - mezofilai, 11 - gèlavandeniai moliuskai

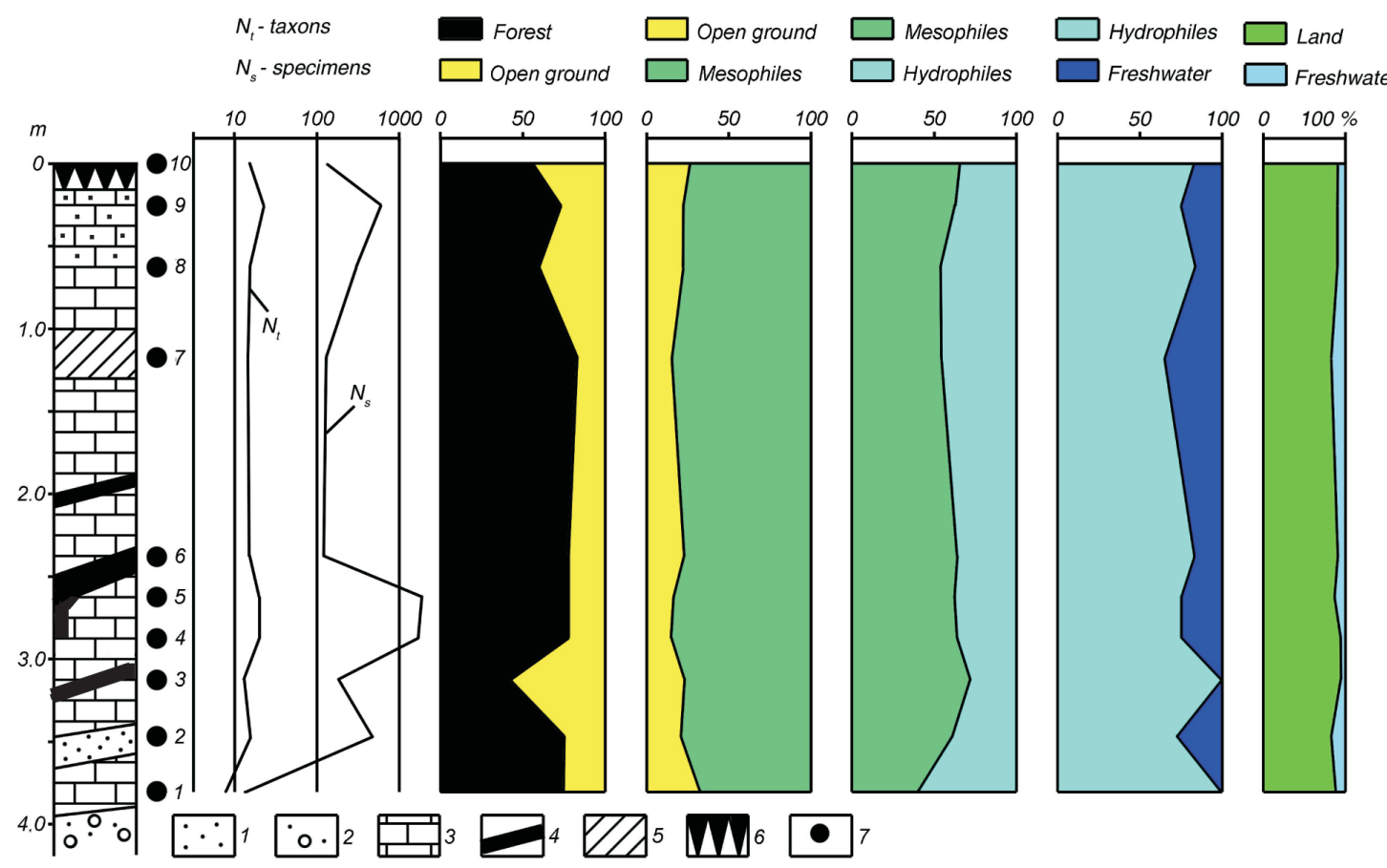

Fig. 6. Bicomponent malacological diagram of calcareous deposits in the Dūkšta section. For explanation, see Fig. 5

6 pav. Dükštos pjūvio karbonatinių nuogulų dvikomponente malakologine diagrama. Paaiškinimus žr. 5 pav. 
Table 4. Radiocarbon dates of wood samples from the Dūkšta section (results by N. D. Mikhailov, 2008)

4 lentelè. Dükštos pjūvio medžio mėginių radiokarboninès datos

\begin{tabular}{|c|c|c|c|c|c|c|c|}
\hline \multirow{2}{*}{ No. } & \multirow{2}{*}{$\begin{array}{l}\text { Sample No. } \\
\text { and depth (m) }\end{array}$} & \multirow{2}{*}{ Material } & \multirow{2}{*}{$\begin{array}{l}\text { Laboratory } \\
\text { number }\end{array}$} & \multirow{2}{*}{$\begin{array}{l}{ }^{14} \mathrm{C} \text { age } \\
\text { (yr BP) }\end{array}$} & \multirow{2}{*}{$\delta^{13} \mathrm{C}$} & \multicolumn{2}{|c|}{ Calibrated age range $B C$ or $A D$} \\
\hline & & & & & & $1 \delta(68.3 \%)$ & $2 \delta(95.4 \%)$ \\
\hline 1 & $\begin{array}{l}\text { No. } 3 \\
2.16\end{array}$ & Wood & IGSB-1355 & $4210 \pm 100$ & -25.5 & $\begin{array}{l}2910-2830 \mathrm{BC} \\
2820-2630 \mathrm{BC}\end{array}$ & $3100-2450 B C$ \\
\hline 2 & $\begin{array}{l}\text { No. } 2 \\
2.84\end{array}$ & Wood & IGSB-1360 & $4390 \pm 115$ & -25.1 & $\begin{array}{l}3330-3210 \mathrm{BC} \\
3180-3160 \mathrm{BC} \\
3120-2900 \mathrm{BC}\end{array}$ & $3400-2650 \mathrm{BC}$ \\
\hline 3 & $\begin{array}{l}\text { No. } 1 \\
3.20\end{array}$ & Wood & IGSB-1354 & $4820 \pm 110$ & -25.8 & $\begin{array}{l}3710-3500 \mathrm{BC} \\
3430-3380 \mathrm{BC}\end{array}$ & $3950-3350 \mathrm{BC}$ \\
\hline 4 & $\begin{array}{l}\text { No. } 4 \\
3.20\end{array}$ & Wood & IGSB-1359 & $5280 \pm 120$ & -24.4 & $4250-3970 \mathrm{BC}$ & $4350-3800 \mathrm{BC}$ \\
\hline
\end{tabular}

The ratio of the forest and non-forest (open-area) mollusc species indicates a forested surrounding which exceeded $50 \%$ of the area and in some cases reached $80 \%$. The dominance of non-forest species in the upper part of the section is related to the increasing human impact, mainly to deforestation. Some climate humidity increment was observed in sandy loam and loamy clay in the depth interval of 1.0 to $1.3 \mathrm{~m}$ (sample 7) where more hydrophilic than freshwater mollusc species were found.

\section{RADIOCARBON DATING}

For radiocarbon dating of calcareous sediments, four samples of wood remnants buried in different levels of the study section were taken (Table 4):3.29-3.11 m (lower), 2.90-2.45 m (middle) and 2.21-2.00 $\mathrm{m}$ (upper). The dating (Table 4) was carried out in 2008 at the Radiocarbon Laboratory of the Belarus National Academy of Sciences, Head Dr. Nikolay Mikhailov.

Wood remains from the three levels in calcareous tufa showed radiocarbon dates from $5280 \pm 120$ to $4210 \pm 100 \mathrm{BP}$. The calibrated dates of the samples cover the time period from 4350 to $2450 \mathrm{BC}$. This means that the calcareous tufa was formed during a short period. The sedimentation rate of calcareous deposits was about 1.5-2 mm / year. During the Atlantic period, thermophilic oak-tree forests were growing here. Analogous dates of buried oak trunks were obtained for the Valakupiai section in Vilnius vicinities about $50 \mathrm{~km}$ east from the Dükšta section (Gaigalas et al., 2007).

The obtained $\delta^{13} \mathrm{C}$ data for wood samples (Table 4) are nearly identical to all the four. The identity of $13 \mathrm{C}$ results indicates the stability of air temperature and warm climatic conditions.

Dry phases indicated by wood remmants in peat interlayers of calcareous tufa were dated to $5280 \pm 120-4820 \pm 100$, $4390 \pm 115$ and $4210 \pm 100 \mathrm{BP}$ and reflected tree falls at that time. The calcareous tufa (Table 2) showed older dates (Table 4). A transformation of some portion of the enclosing rock carbonate material (dead radiocarbon) into a dissolved state of underground water caused a shift of the carbon isotopic composition relative to that determined in the calcareous material deposited from spring water. Thus, the spring calcareous sediments show an older age than wood remants in peat interlayers of the Dūkšta section.

\section{CONCLUSIONS}

The Dūkšta occurrence of fossil malacofauna is the first site of terrestrial molluscs in Lithuania. A trail of calcareous tufa with mollusc shells was formed due to slope processes during the Atlantic climatic optimum of the Holocene and later. Terrestrial fossil molluscs (35 taxa) prevail, freshwater species are rare (6 taxa). Terrestrial fauna had a complex of thermophilic forest species, such as Acicula polita (Hartman), Acanthinula aculeata (Müller), Aegopinella cf. pura (Alder), Bulgaria cana (Held) and Discus cf. rotundatus (Müller) as well as the South-European Carychium tridentatum (Risso) and the West-European Vertigo moulinsiana (Dupuy). From the ecological viewpoint, this malacofauna consists of forest species (11 taxa), open areas species (3 taxa) and mesophiles (21 taxa).

For wood remains from three levels in calcareous tufa, radiocarbon dates range from $5280 \pm 120$ to $4210 \pm 100 \mathrm{BP}$. The calibrated dates of the samples cover the time period from 4350 to $2450 \mathrm{BC}$.

\section{ACKNOWLEDGMENT}

The study was supported by the Lithuanian State Science and Studies Foundation, grant No. T-37/08.

\section{References}

1. Butot L. J. M., Neuteboom W. H. 1958. Over Vertigo moulinsiana (Dupuy) en haar voorkomen in Nederland. Baseria. 22(2-3). 52-63.

2. Gaigalas A., Sanko A., Pazdur A., Pawlyta J., Michczyński A., Budènaite S. 2007. Buried oaks and malacofauna of Holocene oxbow lake sediments in the Valakupiai section, Lithuania. Geologija. 58. 34-48.

3. Johansen A. C. 1904. Om den fossile kvartaere molluskfauna i Danmark og dens relationer til forandringer i klimaet. Land- og ferskvandsmolluskfaunaen. I-IV. København. $1-136$.

4. Meijer T. 1985. The pre-Weichselian non-marine molluscan fauna from Maastricht-Belvédére (Southern Limburg, The Netherlands). Mededelingen Rijks Geologische Dients. 39(1). 75-103. 
5. Kabailienè M., Vaikutienè G., Damušytè A., Rudnickaitė E. 2007. The Stratigraphy and palaeoenvironment of the Northern Part of Curonian Spit based on New Pollen. Diatom. Molluscs and carbonate analysis data. The Quaternary of Western Lithuania: from the Pleistocene Glaciations to the Evolution of the Baltic Sea. Proceedings. The INQUA Peribaltic Group Field Symposium, May 27 - June 02, 2007, Plateliai, Lithuania. Vilnius. 28-29.

6. Rudnickaite E. 2007. Reconstruction of palaeogeography of Pleistocene interglacials according carbonates content. XVII INQUA Congress The Tropics: Heat Engine of the Quaternary, July 27 - August 03, 2007, Cairns, Australia. Abstracts / Quaternary International. 167-168. 356.

7. Рудницкайте Э. Л. 1980. Методика определения карбонатов в разновозрастных моренах плейстоцена. Полевые и лабораторные методы исследования тедниковых отложений. Тезисы докладов межведомственного совещания. РИСО АН ЭССР. Таллин. 121.

8. Рудницкайте Э. Л. 1984. Палеогеографические условия осадконакопления межледниковых отложений в разрезе Жидини по содержанию карбонатов. Палеогеография и стратиграфия четвертичного периода Прибалтики и сопредельных районов. Вильнюс. 203-206.

9. Рудницкайте Э. Л. 1986. Особенности седиментации карбонатов на протяжении межледниковий плейстоцена (по материалам Литвы). История древних озер. Тезисы докладов на VII симпозиуме по истории озер: история озер в дочетвертичное время, в голоцене и формирование полезных ископаемых в озерах. Ленинград, ноябрь 1986. Ленинград: ГО СССР. 106-108.

10. Щербина В. Н. 1958. О методике массового определения карбонатности осадочных пород. Труды института геол. наук АН БССР. Вып. 1. Минск. 131-144.

Aleksander Sanko, Algirdas Gaigalas, Eugenija Rudnickaitė, Monika Melešytė

\section{KARBONATINGŲ NUOGULŲ IŠ DŪKŠTOS APYLINKIŲ NETOLI MAIŠIAGALOS (LIETUVA) HOLOCENO MALAKOFAUNA}

Santrauka

Šioje apylinkejje pirmą kartą Lietuvoje surastos ir ištyrinètos sausumoje gyvenusių holoceno moliuskų liekanos. Moliuskų geldelès ir kriauklès surinktos iš karbonatinių tufų, kurių sudètyje vyrauja kalcitas. Karbonatų (kalcito ir dolomito) kiekis dažnai yra didesnis nei 90\%, o kai kada viršija 99\%. Faunos amžius - holoceno Atlančio klimato optimumas iki šių laikų - patvirtintas radiokarboniniu datavimu. Malakofaunos ekologinè analizè leidžia mums tvirtinti, kad aplinkiniai plotai buvo apaugę tankiu mišku, taip pat padeda ịvertinti temperatūrinị režimą, klimato drègnumą ir žmogaus ūkinès veiklos ịtaką.

Karbonatiniai tufai klostėsi veikiant šlaitų procesams. Sausumos malakofaunos kompleksą sudaro miško rūšys (11 taksonų), atvirų plotų (3 taksonai) ir mezofilai (21 taksonas). Faunos komplekse surastos termofilinès miško rūšys (Acicula polita, Acanthinula aculeata (Müller) Aegopinella cf. pura (Alder), Bulgaria cana (Held) ir Discus cf. rotundatus (Müller), taip pat pasitaikè Pietų Europos (Carychium tridentatum) (Risso)) ir Vakarų Europos rūšių (Vertigo moulinsiana) (Dupuy)).

Medienos likučių karbonatiniuose tufuose iš trijų vertikalių lygių radiokarboninès datos pasiskirsčiusios nuo $5280 \pm 120$ iki $4210 \pm 100 \mathrm{BP}$. Kalibruotos mèginių datos rodo buvus 4350-2450 kalendorinių metų prieš Kristaus gimimą.

Александер Санько, Альгирдас Гайгалас, Евгения Рудницкайте, Моника Мелешите

\section{МАЛАКОФАУНА ГОЛОЦЕНОВЫХ ИЗВЕСТКОВЫХ ОТЛОЖЕНИЙ ИЗ ОКРЕСТНОСТЕЙ ДУКШТЫ ВБЛИЗИ МАЙШЯГАЛЫ (ЛИТВА)}

Резюме

В Центральной Литве обнаружена и исследована наземная фауна моллюсков. Раковины моллюсков в Дукштос встречены в известковых туфах, в составе которых резко преобладает кальцит. Содержание карбонатов (кальцит + доломит) в туфах часто составляет более 90\%, достигая в некоторых пробах более 99\%. Возраст фауны: конец атлантического оптимума голоцена - современность, что подтверждено радиоуглеродным датированием. Экологический анализ фауны позволяет говорить о довольно сильной залесенности окружающей территории, температурном режиме, влажности климата, а также о влиянии хозяйственной деятельности человека.

Карбонатные туфы отложились под действием склоновых процессов. Комплекс наземной малакофауны составляли лесные виды (11 таксонов), открытых пространств (3 таксона) и мезофилы (21 таксон). В комплексе фауны обнаружены термофиловые лесные виды (Acicula polita (Hartman), Acanthinula aculeata (Müller), Aegopinella cf. pura (Alder), Bulgaria cana (Held) и Discus cf. rotundatus (Müller)), а также найдены Южно-Европейский (Carychium tridentatum (Risso)) и Западно-Европейский (Vertigo moulinsiana (Dupuy)) виды.

Карбонатные туфы Дукштос накопились на склоне в результате деятельности родниковых вод. Для древесных остатков из трех уровней разреза карбонатовых туфов получены радиоуглеродные даты распределились в интервале $5280 \pm 120-4210 \pm 100$ ВР. Подсчитанный калибровочный календарный возраст соответствует 4350-2450 лет ВС. 